\title{
Malpighian Tubules in Larvae of Diatraea saccharalis (Lepidoptera; Crambidae): A Morphological Comparison between Non-Parasitized and Parasitized by Cotesia flavipes (Hymenoptera; Braconidae)
}

\author{
Gislei Maria Rigoni' ${ }^{1}$, Helio Conte ${ }^{2}$ \\ ${ }^{1}$ Departamento de Ciências Biológicas, Universidade Estadual do Centro Oeste (UNICENTRO), Guarapuava, \\ Brazil \\ ${ }^{2}$ Departamento de Biotecnologia, Genética e Biologia Celular, Universidade Estadual de Maringá (UEM), \\ Maringá, Brazil \\ Email: gisarigoni@hotmail.com, helconte@gmail.com
}

Received 9 September 2014; revised 11 October 2014; accepted 20 October 2014

Copyright @ 2014 by authors and Scientific Research Publishing Inc.

This work is licensed under the Creative Commons Attribution International License (CC BY). http://creativecommons.org/licenses/by/4.0/

(c) (j) Open Access

\section{Abstract}

In Diatraea saccharalis larvae, the Malpighian tubules are found along the digestive tube, extending from the middle mesenteric region to the end of the posterior intestine, where they come in contact with the rectum to form the cryptonephridium. Scanning and transmission electron microscopy of non-parasitized and parasitized larvae by Cotesia flavipes have indicated that the tubules consist of secretory and reabsorption cells. In parasitized larvae, the occurrence of hemocytes and teratocytes around the tubules is indicative of their role in immunological defense; however, they were not observed in non-parasitized larvae. At day 9 of parasitism, the mitochondria-containing vacuoles and myelin-like figures show signs of degeneration. The results of this study have confirmed that $C$. flavipes manipulates the physiology and biochemistry of $D$. saccharalis because the Malpighian tubules of the parasitized larvae remain active until the parasitoid completes its pupal stage and is released from the host organism.

\section{Keywords}

Endoparasitism, Sugarcane Borer, Morphology, Cotesia flavipes, Biological Control 


\section{Introduction}

Malpighian tubules serve as the main excretory organs of insects. Although they differ among species and various developmental stages of the same species, the tubules are generally long, narrow, and consist of a single layer of epithelial cells [1]-[5]. The tubules are connected to the intestines through a transition region that runs from the mesentery to the proctodeum; they then connect to the hemocoel and deliver fluids to the hemolymph [6]. Besides the excretion of metabolites from the degradation of proteins and purines, these organs are responsible for the maintenance of insect homeostasis, intestinal $\mathrm{pH}$, regulation and secretion of calcium [7], immunological defense, and clearance of toxic substances [8]. During hibernation in crickets, the Malpighian tubules provide minerals for the maintenance of vital processes, which are stored in the form of spherites [9]. In ants, the Malpighian tubules supply metabolites that support symbiotic microorganisms that thrive in the ileum [10], as well as regulate lipid production [11].

The different cell types in insect Malpighian tubules are indicative of its wide range of functions. However, its basic function involves the transport of fluids from the hemolymph to the lumen. In Lepidoptera, the Malpighian tubules consist of two main cell types: the reabsorption cells and the primary or secretory cells. The reabsorption cells vary in terms of quantity and shape of its microvilli, mitochondria, and basal invaginations [2]. The primary cells, which possess secretory functions, are characterized by profound basal invaginations that resemble labyrinths or a profusion of microvilli at the apical region, which comes in contact with the lumen. Mitochondria are located in the basal and apical regions, as well as in the interior of the microvilli. According to Martoja and Ballan-Dufrançais [12], microvilli increase tissue permeability to solutes. Moreover, paracellular transport allows the transfer of fluids across cells that contain septa and into the lumen [13]. Tubules with cells containing the fewest number of microvilli, the thickest basal membranes, and adherent tracheoles are capable of rapidly transporting fluids from the hemolymph [14].

The internal osmolarity of the tubules varies between hypoosmotic and hyperosmotic, which reflects the rate of excretion and reabsorption of water and solutes [13]. A previous study on tubules reported on the presence of aquaporins within the membranes of epithelial cells [15], which are involved in $\mathrm{H}^{+}$-ATPase-mediated active transport that catalyzes the exchange of sodium, potassium or both, and the excretion of organic compounds such as uric acid, alkaloids, and glycosides [16].

The physiology and structure of insect Malpighian tubules can be altered by the presence of parasites, which include viruses, bacteria, protozoans, nematodes, and entomophagous insects. In baculovirus-infected Anticarsia gemmatalis, the Malpighian tubules undergo modifications such as the reorganization of the microvilli, alterations in the cytoplasm, and distortion of the basal membranes [17]. A reduction in the number of apical mitochondria as well as alterations within the microvilli has been observed in the Malpighian tubules of Aedes taeniorhynchus parasitized by nematodes [18]. In Triatoma infestans parasitized by the protozoan Trypanosoma, Malpighian tubules show smaller tracheoles, cellular edema, and a reduction in the number of interdigitations, mitochondria, and microvilli [19].

Cells of the Malpighian tubules of Diatraea saccharalis parasitized by the xenobiont endoparasite Cotesia flavipes have never been studied. However, in intestinal cells, mitochondrial vacuoles have been observed [20], together with the accumulation of spherites [21] and the presence of inorganic compounds in the fat bodies [22].

$D$. saccharalis is of great economic importance to the sugar-alcohol industry because of the considerable damages it has caused in sugarcane plantations [23]. Despite numerous attempts, there is currently no insecticide that can efficiently control this insect, and therefore, in this case, chemical control is not as efficient as biological control [24] [25], which highlights the need for morphological and functional studies that will address these concerns.

\section{Material and Methods}

Larvae of $D$. saccharalis and adult $C$. flavipes were obtained from the Laboratory of Entomology of the Santa Terezinha sugar plant, Iguatemi district, Maringá/Paraná/Brazil (2323'54"S - 5205'36"W). The third instar larvae of $D$. saccharalis were exposed to recently fecundated $C$. flavipes females to facilitate egg laying and parasitism. The insects were maintained in glass tubes, fed on a artificial diet [26], and kept in a $24^{\circ} \mathrm{C}$ incubator at a relative humidity of $64 \% \pm 10 \%$ and a photoperiod of $14 \mathrm{~h}$. Third and fifth instar non-parasitized larvae of $D$. saccharalis were also used as controls, and growth was monitored using the same conditions.

D. saccharalis larvae were cold anesthetized and dissected in an insect salt solution $(0.1 \mathrm{M} \mathrm{NaCl}, 0.1 \mathrm{M}$ 
$\mathrm{Na}_{2} \mathrm{HPO}_{4}$, and $0.1 \mathrm{M} \mathrm{KH}_{2} \mathrm{PO}_{4}$ ) under a stereoscopic microscope. The specimens used in this study included 10 insects at day 5 of parasitism, 10 insects at day 9 of parasitism, and 10 non-parasitized insects. The Malpighian tubules were separated into the rectal portion and the ampullar region.

\subsection{Scanning Electron Microscopy}

The tissues were fixed in 2.5\% glutaraldehyde in $0.1 \mathrm{M}$ phosphate buffer ( $\mathrm{pH} 7.3$ ) for $48 \mathrm{~h}$. Post-fixation was performed using osmium tetroxide and the tissues were dehydrated across an increasing gradient of acetone solutions ( $30 \%$ to $100 \%$ ). To complete the dehydration process, the tissues were subjected to Balzers CPD/030 critical point drying. Immediately after drying, the tissues were placed on aluminum stubs lined with doublesided tape. They were then transferred to the Balzers Union MED 010 sputtering coater and covered with a 10-nm layer of gold. The pieces were examined and photographed using a TM 3000 scanning electron microscope at the Imaging Laboratory of the Departamento de Química of the Universidade Estadual do Centro Oeste Guarapuava/Paraná/Brazil.

\subsection{Transmission Electron Microscopy}

D. saccharalis larvae were cold anesthetized and dissected in the insect salt solution $(0.1 \mathrm{M} \mathrm{NaCl}, 0.1 \mathrm{M}$ $\mathrm{Na}_{2} \mathrm{HPO}_{4}$, and $0.1 \mathrm{M} \mathrm{KH}_{2} \mathrm{PO}_{4}$ ) under a stereoscopic microscope. The specimens used in the study included insects at day 5 of parasitism, 10 insects at day 9 of parasitism, and 10 non-parasitized insects. The Malpighian tubules were separated into the rectal portion and the ampullar region. The tissues were fixed in $2.5 \%$ glutaraldehyde in $0.2 \mathrm{M}$ sodium cacodylate buffer ( $\mathrm{pH}$ 7.4). Post-fixation was performed using $1 \%$ osmium tetroxide using the same buffer for $1 \mathrm{~h}$ and staining was conducted using $2 \%$ aqueous uranyl acetate solution at room temperature overnight. Dehydration was performed using a series of ethanol solutions of increasing concentrations (50\% to $100 \%)$, followed by a solution of ethanol:acetone (1:1) and acetone P.A., both for $10 \mathrm{~min}$. The tissues were then embedded in a mixture of resin and acetone for $7 \mathrm{~h}$ at $4^{\circ} \mathrm{C}$ and in pure resin (Araldite ${ }^{\circledR}$ ) for 24 $\mathrm{h}$ at $4^{\circ} \mathrm{C}$. The resin blocks were sectioned using an ultra-microtome and then stained with uranyl acetate and lead citrate. Analysis and imaging were performed using the transmission electron microscope JEOL JEM-1400 at the Centro de Microscopia do Complexo de Centrais de Apoio à Pesquisa (COMCAP) of the Universidade Estadual de Maringá/Paraná/Brazil and Leo 906 at the Laboratório de Microscopia e Microanálise/IbilceUnesp/São José do Rio Preto/São Paulo/Brazil. The vouchers and data from this work were deposited in the Entomological Collection of the Laboratório de Biotecnologia, Genética e Biologia Celular of the Universidade Estadual de Maringá, Pr, Brazil.

\section{Results}

The ampullar and rectal regions of the Malpighian tubules of $D$. saccharalis and those parasitized by $C$. flavipes for 5 and 9 days showed the following characteristics;

\subsection{Non-Parasitized Larvae}

The insertion sites of the tubules in the intestine occurred at the transition region between the mesentery and the proctodeum through two saccular ampullae, which were positioned laterally and symmetrically in the intestinal muscles. The tubules diverged from the ampullae and continued toward the anterior mesentery, devoid of tracheoles. The cells that were part of this structure were arranged in the form of a bead collar with centralized nuclei (Figure 1(a)).

The ampullar region contained cells with a basal lamina, numerous labyrinth-like invaginations in the plasma membrane, and centrally positioned nuclei. Electron-dense mitochondria were observed in the basal and apical regions, with the apical surface containing microvilli that were in contact with the lumen (Figure 2(e)).

The Malpighian tubules in the rectal region lacked hemocytes and showed numerous tracheoles (Figure 2(a)). The tracheoles allowed the Malpighian tubules to attach to each other, as well as to the perinephral membrane and the rectum, thus forming the cryptonephridium (Figure 2(b)). In this region, two types of cells constitute the tubules; one cell type contains a small cytoplasm and few mitochondria, which characterizes absorption cells. The typical primary or secretory cells were characterized by a large cytoplasm, microvilli, and extensive and well-developed basal invaginations (Figure 3(b)). 


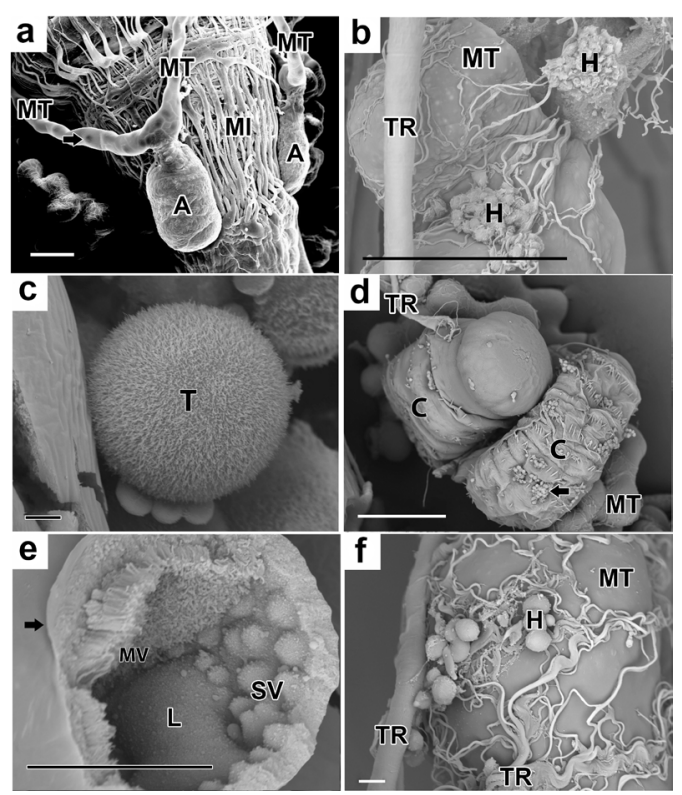

Figure 1. Scanning electron microscopy of Malpighian tubules of Diatraea saccharalis larvae. (a) Non-parasitized ampulla; (MT) Malpighian tubules, (arrow) nucleus, (A) ampulla, (IM) intestinal muscle. Bar $=200 \mu \mathrm{m}$. (b) MT at day 5 of parasitism with the formation of hemocytes clusters; (MT) Malpighian tubules, (TR) tracheoles, and (H) hemocytes. Bar $=100 \mu \mathrm{m}$. (c) Rectum at day 9 of parasitism (T) detail of a teratocyte. Bar $=5 \mu \mathrm{m}$. (d) Ampulla at day 9 of parasitism; (C) Cotesia flavipes larva; (MT) Malpighian tubules, (TR) tracheoles, (arrow) hemocytes attached to the parasitoid. Bar $=200 \mu \mathrm{m}$. (e) Broken rectum at day 9 of parasitism (arrow) basal lamina; (MV) microvilli, (L) lumen, (SV) secretory vesicles. Bar $=30 \mu \mathrm{m}$. (f) Ampulla at day 9 of parasitism (TR) tracheoles, (MT) Malpighian tubules, (H) hemocytes. Bar $=50 \mu \mathrm{m}$.

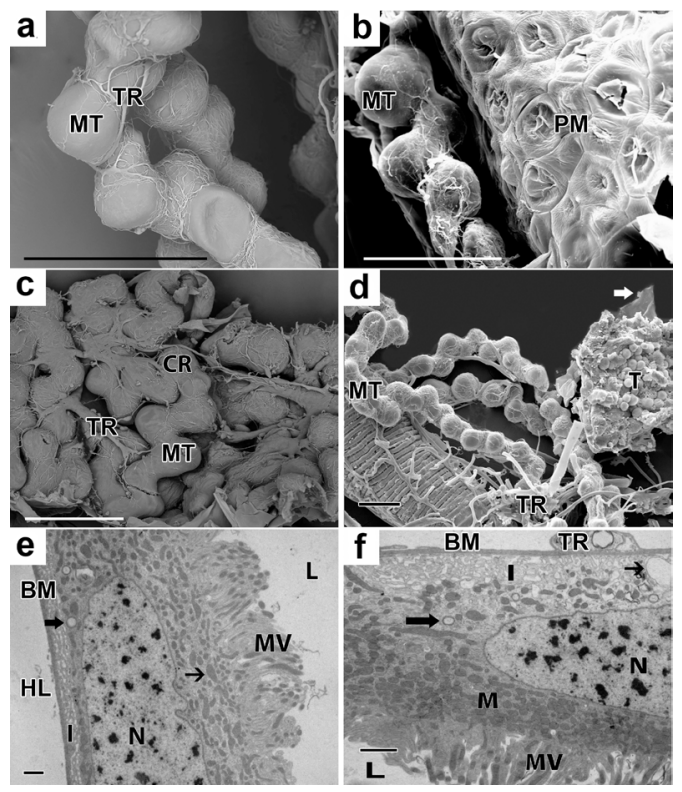

Figure 2. Scanning electron microscopy of Diatraea saccharalis larvae. (a) Non-parasitized rectum region; (MT) Malpighian tubules, (TR) tracheoles. Bar $=300 \mu \mathrm{m}$. (b) Non-parasitized rectum (MT) Malpighian tubules, and (PM) perinephral membrane. Bar $=200 \mu \mathrm{m}$. (c) Rectum at day 5 of parasitism; (CR) cryptonephridium, (MT) Malpighian tubules, and (TR) tracheoles. Bar $=500 \mu \mathrm{m}$. (d) Rectum at day 9 of parasitism; (MT) Malpighian tubules, (TR) tracheoles, (arrow) perinephral membrane, $(\mathrm{T})$ teratocytes. Bar $=500 \mu \mathrm{m}$. Transmission electron microscopy of Malpighian tubules of Diatraea saccharalis larvae. (e) Non-parasitized ampulla; (BM) basal lamina, (I) basal invaginations, (arrrow) electron-lucent vesicles, (N) nucleus, (HL) hemolymph, (L) lumen, (fine arrow) mitochondria, and (MV) microvilli. Bar $=1 \mu \mathrm{m}$. (f) Ampulla at day 9 of parasitism; (BM) basal lamina, (I) basal invaginations, (arrow) electron-lucent vesicles, (fine arrow) vacuole, (N) nucleus, (TR) tracheoles, (L) lumen, (M) mitochondria, and (MV) microvilli. Bar $=1 \mu \mathrm{m}$. 

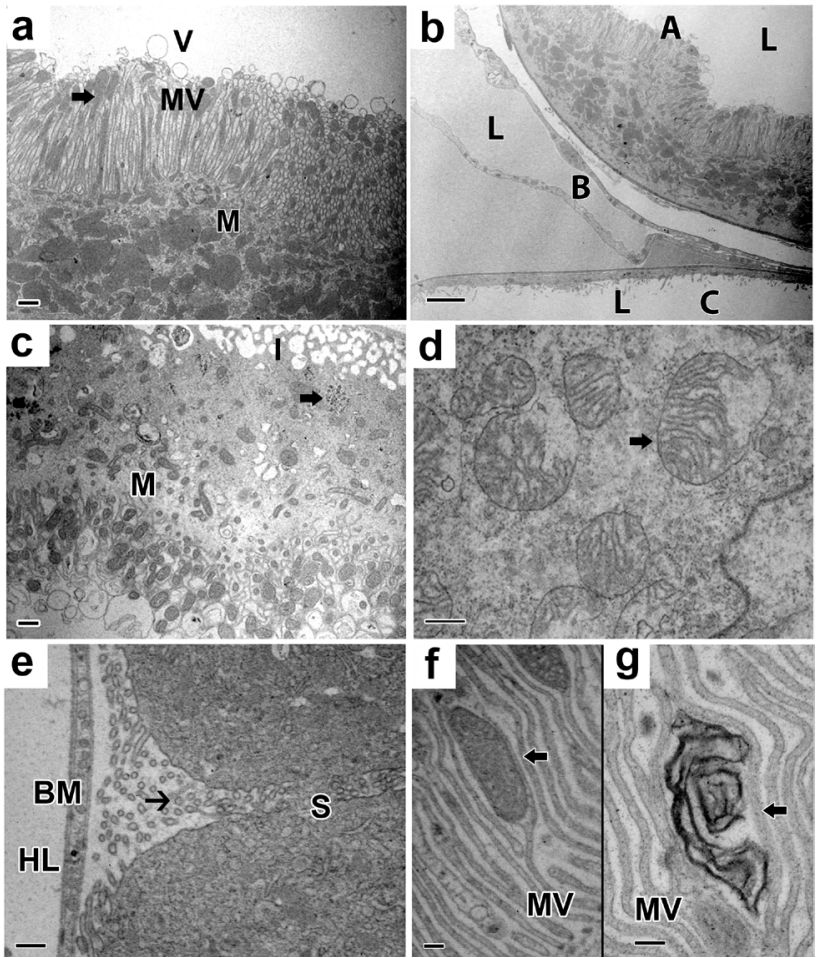

Figure 3. Transmission electron microscopy of Malpighian tubules of Diatraea saccharalis larvae. (a) Non-parasitized rectal region; (M) electron-dense mitochondria, (MV) micovilli, (arrow) mitochondria inside microvilli, and (V) electron-lucent vesicles released in the lumen. Bar $=0.5 \mu \mathrm{m}$. (b) Non-parasitized rectum, two types of cells forming the Malpighian tubules (A) Secretory, (B) and (C) reabsorption cells, (L) lumen. Bar $=2 \mu \mathrm{m}$. (c) Rectum at day 5 of parasitism; (I) basal invaginations, (arrow) glycogen granules. $(\mathrm{M})$ mitochondria, Bar $=0.2 \mu \mathrm{m}$. (d) Rectum at day 9 of parasitism; (arrow) vacuole-containing mitochondria. Bar $=1 \mu \mathrm{m}$. (e) Rectum at day 9 of parasitism; (BM) double-layered basal lamina, (HL) hemolymph, (S) intercellular space, and (arrow) globular and stretched vesicles. Bar $=0.5 \mu \mathrm{m}$. (f) Rectum at day 5 of parasitism; (MV) stick-shaped microvilli, (arrow) mitochondria. Bar $=0.2 \mu \mathrm{m}$. (g) Rectum at day 5 of parasitism; (arrow) myelin body, (MV) stick-shaped microvilli. Bar $=0.2 \mu \mathrm{m}$.

\subsection{Parasitized Larvae}

The parasitized larvae showed a significantly higher number of hemocytes and teratocytes attached to the Malpighian tubules (Figure 1(b), Figure 1(c), and Figure 1(f)). In the broken tubules, tracheoles, basal membranes, microvilli, and secretory vesicles were observed (Figure 1(e)). At day 9 of parasitism, the $C$. flavipes larvae were attached to the Malpighian tubules and hemocytes were observed on the parasitoid (Figure 1(d)). Tracheoles were attached to the basal lamina, whereas labyrinth-like basal invaginations, electron-lucent vacuoles, polymorphic mitochondria across the cytoplasm, and centrally positioned nuclei were evident (Figure 2(f)). In the Malpighian tubules of larvae at day 5 of parasitism, the perinephral membrane and the cryptonephridium formed a compact structure in the rectal region (Figure 2(c)). Moreover, vesicles in the lumen, basal invaginations, and glycogen granules spread across the cytoplasm were observed (Figure 3(c)). The cells of the Malpighian tubules from days 5 and 9 of the parasitized larvae showed myelin bodies and vacuole-containing mitochondria (Figure 3(d)). At day 9 of parasitism, teratocytes were observed between the perinephral membrane and the Malpighian tubules, which formed the cryptonephridium (Figure 2(d)). The presence of an intercellular space where globular and stretched vesicles could be found suggested the occurrence of paracellular transport (Figure 3(e)). Stick-shaped microvilli were also observed, with some containing mitochondria and myelin bodies (Figure 3(f) and Figure 3(g)).

\section{Discussion}

Similar to the majority of the Lepidoptera, the Malpighian tubules of D. saccharalis larvae have been extensively described [2] [27]. The cryptonephridium, which can be found at the end of the rectum, is responsible for 
the reabsorption of water and salts, thus allowing the maintenance of homeostasis [2] [28] [29]. The fusion of two tubules could be observed on the wall of the rectum [30].

The larvae of $D$. saccharalis have Malpighian tubules that were comprised of two types of cells that can be found in both the rectal and the ampullar regions: primary or secretory cells and reabsorption cells. The primary cells have centrally positioned nuclei, labyrinth-like and well-developed basal invaginations containing numerous mitochondria, and microvilli in the apical region that come in contact with the lumen. Mitochondria can also be found within the microvilli. This characteristic of the primary or secretory cells has been described for various insect orders, including Coleoptera [31], Díptera [32] [33], Hemiptera [34] and Hymenoptera [6].

The cytoplasm of the primary cells contained electron-dense vesicles, vacuoles, and vesicles protruding into the lumen with material from the hemolymph. Myelin bodies could be observed in the microvilli of parasitized cells, which have resulted from the elimination of cellular residues or organelles [35]. However, mineral formations such as those described in other organs [9] [19] [21] [36] were not observed in the Malpighian tubules of $D$. saccharalis.

Maddrell [7] previously suggested that the main function of the Malpighian tubules was to transport fluids from the hemolymph to the lumen. In addition to passive transport, it has also been suggested that Malpighian tubules are involved in $\mathrm{H}^{+}$-ATPase-mediated active transport [16], which is in agreement with the high number of mitochondria and tracheoles observed in $D$. saccharalis. No tracheoles were found attached to the $D$. saccharalis Malpighian tubules; however, glycogen deposits were observed in the cytoplasm, and mitochondria could be found inside the microvilli. These polymorphic, electron-dense organelles were observed in larval cells up to day 5 of parasitism. In some cells, mitochondria showed vacuoles and loss of the matrix, which indicated degeneration, as described by [20] for the mid-intestinal cells of $D$. saccharalis parasitized by the same parasitoid.

Blunn [36] previously described different trans-epithelial transport mechanisms, namely through the cytoplasm, with and without vesicles, or through the intercellular spaces. In the rectal region of $D$. saccharalis at day 9 of parasitism, inter-membrane spaces were observed, which indicated that paracellular movement of small vesicles played a role in the excretion of toxins, as suggested by [13] for other insects. The paracellular transport observed in different species was undetected in resting cells [37]-[39].

In addition to fluid transport from the hemolymph to the tubules and later to the rectum, the Malpighian tubules are also responsible for the reabsorption of water and salts for homeostasis maintenance. This is the role of the reabsorption cells, which showed smaller cytoplasm, fewer microvilli, and larger lumen, thus allowing the rapid passage of fluids [11] [28] [31]. In D. saccharalis, the reabsorption cells in the ampullar and the rectal regions, where the cryptonephridium is located, showed an increase in reabsorption capacity [40].

Koinobiontparasites lead to alterations in the host hemolymph composition, the endocrine system, and the immunological system. However, the maintenance of the integrity of the host organs is paramount for the life cycle of the parasitoid [41] [42]. In D. saccharalis parasitized by C. flavipes, no morphological alterations were detected in the Malpighian tubules and the ampullae, except for the presence of hemocytes and teratocytes. These data confirm that $C$. flavipes, which is a koinobiont, gregarious endoparasite with regulatory activities, is capable of manipulating the host's physiology for its benefit [43]-[45]. The activity of the parasitoid may be influenced by a decrease in the number of hemocytes, alterations in the diet, host metamorphosis, non-encapsulation, and nodulation [46].

The manipulation of the host physiology and biochemistry occurs through venom secretion, ovarian proteins, and symbiotic viruses such as the polydnavirus that is injected together with the eggs during oviposition. As a surviving strategy inside the host, the parasitoids release cells derived from the extra-embryonic tissue or the teratocytes [47]-[49]. D. saccharalis larvae parasitized by $C$. flavipes were compared with non-parasitized larvae and an initial increase in the number of hemocytes adhering to the Malpighian tubules, the intestine, and the parasitoid bodies was observed. According [50], the host immune response and the number of hemocytes decreased as the parasitoid developed. Nunes and Gregório [51] showed that $C$. flavipes induces ultra-structural modifications in one type of $D$. saccharalis hemocyte, the oenocyte, which can affect the defense mechanisms of the host due to the production/activation of the prophenoloxidase system.

In $D$. saccharalis, teratocytes were observed mainly in the rectal region at day 9 of parasitism. The number of teratocytes can change depending on the extent of degeneration and on the nutrient consumption by the parasitoid [52], as these cells contribute to the maintenance of the endoparasite [53].

No polydnaviruses were observed in the Malpighian tubules of parasitized D. saccharalis larvae, possibly 
because this organ was not a target of this virus [17], whereas they were detected in A. gemmatalis parasitized by a baculovirus and in Bombyx mori infected by a nucleopolyedrovirus [53].

\section{Acknowledgements}

Centro de Microscopia do Complexo de Centrais de Apoio à Pesquisa (COMCAP) from the Universidade Estadual de Maringá/Paraná/Brazil, Laboratório de Microscopia e Microanálise/Ibilce-Unesp/São José do Rio Preto/São Paulo and NAP/MEPA ESALQ/USP/Piracicaba/Paraná/Brazil.

\section{References}

[1] Wigglesworth, V.B. (1974) The Principles of Insect Physiology. 7th Edition, Chapman and Hall, London, 827 p.

[2] Chapman, R.F. (1998) The Insects: Structure and Function. The English Universities Press, New York, 788 p. http://dx.doi.org/10.1017/CBO9780511818202

[3] Martinelli, A. (1998) Histoquímica e Ultra-Estrutura dos Túbulos de Malpighi de Operárias de Atta sexdens rubropilosa Forel, 1908 (Hymenoptera: Formicidae). Dissertação Mestrado. Universidade Estadual Paulista, Rio Claro.

[4] Triplehorn, C.A. and Johnson, N.F. (2011) Estudo dos Insetos-Tradução da 7 a Edição de Borror and Delong’s Introduction to the Study of Insects. São Paulo, Cengage Learning, 808 p.

[5] Rafael, J.A., Melo, G.A.R., Carvalho, C.J.B., Casari, S.A. and Constantino, R. (2012) Insetos do Brasil: Diversidade e Taxonomia. Editora Ltda-ME, Holos.

[6] Cruz-Landim, C. (2009) Abelhas: Morfologia e Função de Sistemas. Ed UNESP, São Paulo, 384 p.

[7] Maddrell, S.H.P., Herman, W., Mooney, R.L. and Overton, J.A. (1991) 5-Hydroxytryptamine: A Second Diuretic Hormone in Rhodnius prolixus. Journal of Experimental Biology, 156, 557-566.

[8] Beyenbach, K.W., Skaer, H. and Dow, J.A.T. (2010) The Developmental, Molecular, and Transport Biology of Malpighian Tubules. Annual Review Entomology, 55, 351-374. http://dx.doi.org/10.1146/annurev-ento-112408-085512

[9] Delakorda, S.L., Letofsky-Papst, I., Novak, T., Hofer, F. and Pabst, M.A. (2009) Structure of the Malpighian Tubule Cells and Annual Changes in the Structure and Chemical Composition of Their Spherites in the Cave Cricket Troglophilus neglectus Krauss, 1878 (Rhaphidophoridae, Saltatoria). Arthropod Structural Development, 38, 315-327. http://dx.doi.org/10.1016/j.asd.2009.02.001

[10] Bution, M.L., Caetano, F.H. and Zara, F.J. (2007) Contribuição dos Túbulos de Malpighi para a Manutenção de Micoorganismos Simbiontes em Cephalotini. Biológico, 69, 339-343.

[11] Arab, A. and Caetano, F.H. (2002) Segmental Specializations in the Malpighian Tubules of the Fire Ant Solenopsis saevissima Forel 1904 (Myrmicinae): An Electron Microscopical Study. Arthropod Structure \& Development, 30, 281292. http://dx.doi.org/10.1016/S1467-8039(01)00039-1

[12] Martoja, R. and Ballan-Dufrançais, C. (1984) The Ultrastructure of the Digestive and Excretory Organs. In: King, R.C. and Akai, H., Eds., Insect Ultrastructure, Vol. 2, Plenum Press, New York, 119-261. http://dx.doi.org/10.1007/978-1-4613-2715-8_6

[13] Maddrell, S.H.P. and O’Donnell, M.J. (1992) Insect Malpighian Tubules: V. ATPase Action in Ion and Fluid Transport. Journal of Experimental Biology, 172, 417-429.

[14] Ryerse, J.S. (1979) Developmental Changes in Malpighian Tubule Cell Structure. Tissue and Cell, 11, 533-551. http://dx.doi.org/10.1016/0040-8166(79)90061-2

[15] Spring, J.H., Robichaux, R.S. and Hamlin, J.A. (2009) The Role of Aquaporins in Excretion in Insects. Journal of Experimental Biology, 212, 358-362. http://dx.doi.org/10.1242/jeb.024794

[16] O’Donnell, M.J., Maddrell, S.H.P. and Gardiner, B.O.C. (1983) Transport of Uric Acid by the Malpighian Tubules of Rhodnius prolixus and the Other Insects. Journal of Experimental Biology, 103, 169-184.

[17] Cordeiro, B.A. (2007) Efeitos patológicos nos túbulos de Malpighi de Anticarsia gemmatalis causados pela infecção por recombinantes do baculovírus Anticarsia gemmatalis multiple nucleopolyhedrovirus (AgMNPV). Dissertação (Mestrado em Biologia Molecular), Universidade de Brasília, Brasília, 90 p.

[18] Bradley, T.J. (1985) The Excretory Sistem: Structure and Function. Insect Physiology, Biochemistry and Pharmacology, 4, 421-465.

[19] Schuab, G.A. and Schnitker, A. (1988) Influence of Blastocrithidia triatome (Trypanosomatidae) on the Reduviid Bug Triatoma infestans: Alterations in the Malpighian Tubules. Parasitology Research, 75, 88-97. http://dx.doi.org/10.1007/BF00932706

[20] Pinheiro, D.O., Silva, M.D. Gregório, E.A. (2010) Mitochondria in the Midgut Epithelial Cells of Sugarcane Borer Pa- 
rasitized by Cotesia flavipes (Cameron, 1891). Brazilian Journal of Biology, 70, 163-169. http://dx.doi.org/10.1590/S1519-69842010000100023

[21] Pinheiro, D.O., Conte, H. and Gregório, E.A. (2008) Spherites in the Midgut Epithelial Cells of the Sugarcane Borer Parasitized by Cotesia flavipes. Biocell, 32, 61-67.

[22] Pinheiro, D.O., Zucchi, T.D., Zucchi, O.L.A.D., Nascimento Filho, V.F., Almeida, E. and Cônsoli, F.L. (2010) Iorganic Elements in the Fat Bodies of Diatraea saccharalis (Lepidoptera: Crambidae) Larvae Parasitized by Cotesia flavipes (Hymenoptera: Braconidae). Comparative Biochemistry and Physiology Part B: Biochemistry and Molecular Biology, 156, 273-278. http://dx.doi.org/10.1016/j.cbpb.2010.04.004

[23] Roc, R.M., Hammond Jr., A.M., Reagan, T.E. and Hensley, S.D. (1981) A Bibliography of the Sugarcane Borer Diatraea saccharalis (Fabricius) 1887-1980. US Agricultural Research Service (Southern Region), US Department of Agriculture, New Orleans.

[24] William, J.R., Metcalfe, J.R., Mungomery, R.W. and Mathes, R. (1969) Pests of Sugarcane. Elsevier Publ. Co., New York, $586 \mathrm{p}$.

[25] Guagliumi, P. (1973) Pragas da cana-de-açúcar no nordeste do Brasil. Instituto do Açúcar e do Álcool, Rio de Janeiro.

[26] Hensley, S.D. and Hammond, A.M. (1968) Laboratory Techniques for Rearing the Sugarcane Borer on Artificial Diet. Journal of Economical Entomology, 61, 1742-1743.

[27] Gullan, P.J. and Cranston, P.S. (2010) The Insects: An Outline of Entomology. 4th Edition, Willey Blackwell Publishing, Hoboken, 584 p.

[28] Richards, O.W. and Davies, R.G. (1994) Imm's General Textbook of Entomology, Vol. 2. 10ª Edition, Chapman and Hall, London.

[29] Levy, S.M., Falleiros, A.F., Moscardi, F., Gregório, E.A. and Toledo, L.A. (2004) Morphological Study of the Hindguth in Larvae of Anticarsia gemmatalis Hübner (Lepidoptera: Noctuidae). Neotropical Entomology, 33, 427-431. http://dx.doi.org/10.1590/S1519-566X2004000400005

[30] Rigoni, G.M., Tomotake, M.E.M. and Conte, H. (2004) Morphology of Malpighian Tubules of Diatraea saccharalis (F.) (Lepidoptera: Crambidae) at Final Larval Development. Cytologia, 69, 1-6. http://dx.doi.org/10.1508/cytologia.69.1

[31] Green, L.F. (1981) Cryptonephric Malpighian Tubule System in a Dipteran Larva, the New Zeland Glow-Worm, Arachnocampa luminosa (Diptera: Mycetophilidae): A Structural Study. Chromosoma, 83, 619-643.

[32] Bradley, T.J., Sturat, A.M. and Satir, P. (1982) The Ultrastructure of the Larval Malpighian Tubule of a Saline-Water Mosquito. Scanning Electron Microscopy, 14, 759-773.

[33] Hazelton, S.R., Felegenhauer, B.E. and Spring, J.H. (2001) Ultrastructural Changes in the Malpighian Tubules of the House Cricket, Acheta domesticus, at the Onset of Diuresis: A Time Study. Journal of Morphology, 247, 80-92. http://dx.doi.org/10.1002/1097-4687(200101)247:1<80::AID-JMOR1004>3.0.CO;2-X

[34] Martine, S.V., Nascimento, S.B. and Morales, M.M. (2007) Rhodnius prolixus Malpighian Tubules and Control of Diuresis by Neurohormones. Anais da Academia Brasileira de Ciências, 79, 87-95. http://dx.doi.org/10.1590/S0001-37652007000100011

[35] Rivers, D.B., Ergin, E. and Uçkan, F. (2007) Cell Death in the Host-Parasitoid Relationship. In: Corvin, A.J., Ed., New Developments in Cell Apoptosis Research, Nova Science Publishers, New York, 69-96, 287 p.

[36] Wu, G.X., Gao, X., Ye, G.Y., Li, K., Hu, C. and Cheng, J.A. (2005) Ultrastructural Alterations in Midgut and Malpighian Tubules of Boettcherisca peregrine Exposure to Cadmium and Copper. Tissue and Cell, 37, 223-232.

[37] Blunn, M.S. (1985) Fundamentals of Insect Physiology. John Wiley \& Sons, New York, 112.

[38] Nicholls, S.P. (1983) Ultrastructural Evidence for Paracellular Fluid Flow in the Malpighian Tubules of a Larval Mayfly. Tissue and Cell, 15, 627-637. http://dx.doi.org/10.1016/0040-8166(83)90012-5

[39] Green, L.F., Berqquist, P.R. and Bullivant, S. (1980) The Structure and Function of the Smooth Septate Junction in a Transporting Epithelium: The Malpighian Tubules of the New Zealand Glow-Worm Arachnocampa luminosa. Tissue and Cell, 12, 365-381.

[40] Hernández, C.S., Gutiérrez, A.M., Vargas-Janzen, A., Noria, F., González, E., Ruiz, V. and Whittembury, G. (2002) Fluid Secretion in Rhodnius upper Malpighian Tubules (UMT): Water Osmotic Permeabilities and Morphometric Studies. Journal of Morphology, 251, 73-82.

[41] Fermino, F., Conte, H. and Falco, J.R. (2010) Analysis of Nucleus Activity in Malpighian Tubules of Diatraea saccharalis (Fabricius) (Lepidoptera: Crambidae) Larvae by Critical Electrolyte Concentration. Neotropical Entomology, 39, 568-571. http://dx.doi.org/10.1590/S1519-566X2010000400016

[42] Quicke, D.L.J. (1997) Parasitic Wasps. Chapman and Hall, London, 470 p. 
[43] Sheng, L., Falabela, P., Kuriachan, I., Vinson, S.B., Borst, D.W., Malva, C. and Pennacchio, F. (2003) Juvenile Hormone Synthesis, Metabolism, and Resulting Haemolynph Titre in Heliothis virescens Larvae Parasitized by Toxoneuron nigriceps. Journal of Insect Physiology, 49, 1021-1030. http://dx.doi.org/10.1016/S0022-1910(03)00185-9

[44] Pennacchio, F. and Strand, M.R. (2006) Evolution of Developmental Strategies in Parasitic Hymenoptera. Annual Review of Entomology, 51, 233-258. http://dx.doi.org/10.1146/annurev.ento.51.110104.151029

[45] Pinto, A.S., Garcia, J.F. and Botelho, P.S.M. (2006) Controle biológico de pragas da cana-de-açúcar. In: Pinto, A.S., Nava, D.E., Rossi, M.M. and Malerbo-Souza, D.T., Eds., Controle biológico de pragas: Na prática, FEALQ, Piracicaba, 65-74, 287 p.

[46] Jervis, M.A., Ellers, J. and Harvey, J.A. (2008) Resource Acquisition, Allocation, and Utilization in Parasitoid Reproductive Strategies. Annual Review of Entomology, 53, 361-385. http://dx.doi.org/10.1146/annurev.ento.53.103106.093433

[47] Lavine, M.D. and Strand, M.R. (2002) Insect Hemocytes and Their Role in Immunity. Insect Biochemistry and Molecular Biology, 32, 1295-1309. http://dx.doi.org/10.1016/S0965-1748(02)00092-9

[48] Beckage, N.E. and Gelman, D.B. (2004) Wasp Parasitoid Disruption of Host Development: Implications for New Biologically Based Strategies for Insect Control. Annual Review of Entomology, 49, 299-330. http://dx.doi.org/10.1146/annurev.ento.49.061802.123324

[49] Lopes, C.S. (2009) Regulação do desenvolvimento e resposta immune de lagartas de Diatraea saccharalis (Fabricius) (Lepodoptera: Cambridae) por Cotesia Flavipes (Cameron) (Hymenoptera: Braconidae). Dissertação Escola de Agricultura Luiz de Queiroz, Piracicaba.

[50] Nunes, C.C.C. and Gregório, E.A. (2005) Ultrastructural and Cytochemical Characterization of the Oenocytoid in Larvae of Diatraea saccharalis (Lepidoptera: Pyralidae) Parasitized by the Wasp Cotesia flavipes (Hymenoptera: Braconidae). Naturalia Rio Claro, 30, 28-33.

[51] Basio, N.A. and Kim, Y. (2005) A Short Review of Teratocytes and Their Characters in Cotesia plutellae (Braconidae: Hymenoptera). Journal of Asia-Pacific Entomology, 8, 211-217. http://dx.doi.org/10.1016/S1226-8615(08)60093-X

[52] Dahlman, D.H. and Vinson, S.B. (1993) Teratocytes: Developmental and Biochemical Characteristics. In: Beckage, N.E., Thompson, S.N. and Federici, B.A., Eds., Parasites and Pathogens of Insects, Vol. 1, Academic Press, New York, 145-166.

[53] Takeda, K.I. (2009) Obtenção de seqüências expressas em túbulos de Malpighi de híbridos de bicho-da-seda infectados pelo “Bombyx mori” nucleopoliedrovírus BmMNPV. Dissertação Mestrado em Genética e Melhoramento, UEM, Maringá. 
Scientific Research Publishing (SCIRP) is one of the largest Open Access journal publishers. It is currently publishing more than 200 open access, online, peer-reviewed journals covering a wide range of academic disciplines. SCIRP serves the worldwide academic communities and contributes to the progress and application of science with its publication.

Other selected journals from SCIRP are listed as below. Submit your manuscript to us via either submit@scirp.org or Online Submission Portal.
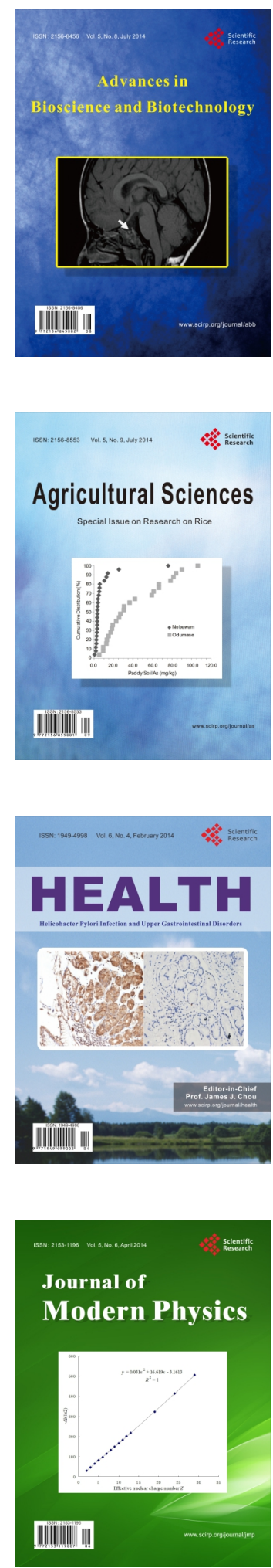
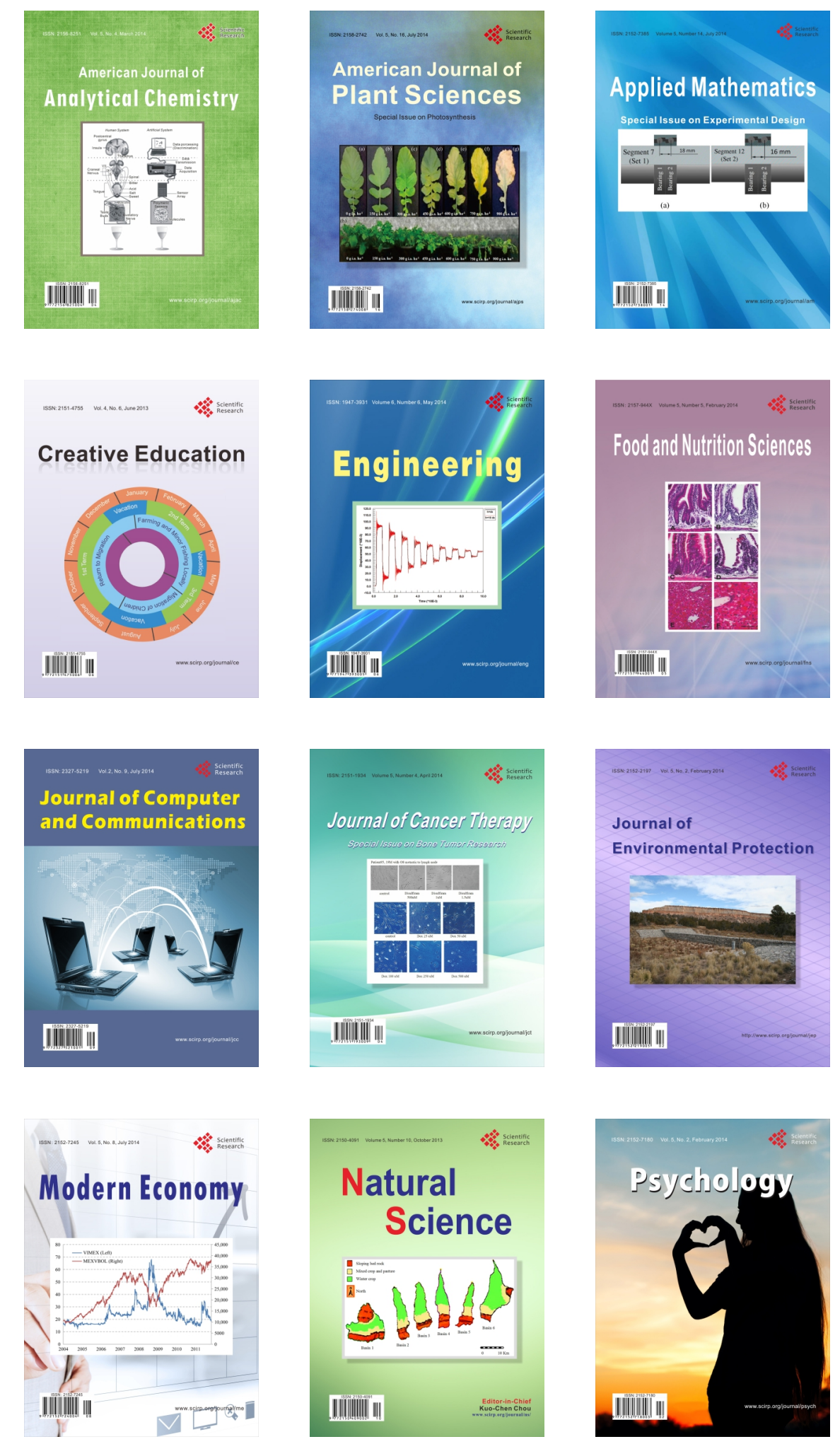